\title{
Mari Pakai Masker Putus Penyebaran COVID-19
}

\author{
Rani Lisa Indra ${ }^{1}$, Bayu Saputra ${ }^{2}$, Erna Marni ${ }^{3}$ \\ ${ }^{1,2,3}$ Program Studi Sarjana Keperawatan, STIKes Hang Tuah Pekanbaru, Riau, Indonesia \\ e-mail:r4ni35@gmail.com
}

Submitted : 12/11/2020

Accepted: 26/11/2020

Published: 11/01/2021

\begin{abstract}
COVID-19 is a disease that attacks the respiratory system from no symptoms to death. Because more and more individuals are infected with COVID-19 who are asymptomatic, wearing a mask is one of the ways to prevent it. The purpose of this community service activity is to break the chain of the spread of COVID-19 and increase public awareness to always use masks when leaving the house. The target of this activity is the traders who sell at the Pekanbaru Dupa Market. The method of implementing this activity is in the form of social service by distributing cloth masks for free and providing information about the use of cloth masks with the target of changing the behavior of traders by always wearing masks when selling. The output of this service activity is publication in a community service journal. The result of this activity was the distribution of 100 cloth masks for free to traders. However, when the evaluation was carried out a week later, it turned out that there were still many traders who did not wear masks when selling. It is hoped that traders will increase awareness of wearing masks as a way to prevent transmission of COVID-19.
\end{abstract}

Keywords: COVID-19, masks, traders

\begin{abstract}
Abstrak
COVID-19 merupakan penyakit yang menyerang system pernapasan mulai dari tanpa gejala sampai dapat menimbulkan kematian. Karena semakin banyaknya individu terinfeksiCOVID-19 yang tanpa gejala, maka menggunakan masker adalah salah satu cara pencegahannya. Tujuan kegiatan pengabdian masyarakat ini adalah untuk memutus rantai penyebaran COVID-19 dan meningkatkan kesadaran masyarakat untuk selalu menggunakan masker saat keluar rumah.Sasaran kegiatan ini adalah para pedagang yang berjualan di Pasar Dupa Pekanbaru. Metode pelaksanaan kegiatan ini berupa bakti social dengan membagikan masker kain secara gratis dan pemberian informasi tentang penggunaan masker kain dengan target kegiatan terjadinya perubahan perilaku pedagang dengan selalu memakai masker saatberjualan. Luaran dari kegiatan pengabdian ini adalah publikasi pada jurnal pengabdian masyarakat.Hasil dari kegiatan ini adalah dibagikannya masker kain sebanyak 100 buah secara gratis kepada para pedagang.Namun saat evaluasi dilakukan seminggu setelahnya, ternyata masih banyak parapedagang yang tidak memakai masker saat berjualan. Diharapkan kepada para pedagang untuk lebih meningkatkan kesadaran dalam memakai masker sebagai salah satu cara mencegah penularan COVID-19.
\end{abstract}

Kata Kunci: covid-19, masker, pedagang

\section{PENDAHULUAN}

Saat ini dunia sedang mengalami pandemic akibat wabah penyakit baru yang disebut Coronavirus Disease (COVID-19) yang terjadi akibat infeksi virus corona (SARS-CoV-2).Virus corona merupakan kelompok virus yang menyebabkan terjadinya gangguan pada system pernapasan mulai dari gangguan ringan sampai gangguan berat (Susilo dkk,
2020).COVID-19 ini telah mengenai 231 negara termasuk Indonesia. Berdasarkan data WHO per 22 April 2020, kasus COVID-19 terkonfirmasi di seluruh dunia berjumlah 2.471.136 kasus dengan kematian sebanyak 169.006 kasus (6\%)(Satuan Tugas Penanganan COVID19, 2020).

Kasus COVID-19 terkonfirmasi pertama kali di Indonesia sebanyak 2 kasus 
pada 2 Maret 2020, namun per 22 April 2020 di Indonesia telah terdapat sekitar 7.418 kasus terkonfirmasi positif COVID19 dengan kematian sebanyak 635 kasus $(8,5 \%)$ dan sembuh sebanyak 913 kasus $(12,3 \%)$. Sedangkan di Riau kasus terkonfirmasi sebanyak 35 kasus, sembuh sebanyak 9 kasus dan meninggal 4 kasus (Satuan Tugas Penanganan COVID-19, 2020).

Peningkatan yang sangat drastis pada jumlah kasus terkonfirmasi dalam kurun waktu 2 bulan ini berkaitan dengan proses transmisi/penularan penyakit yang utamanya menyebar dari manusia ke manusia melalui droplet yang keluar saat batuk, bersin atau berbicara, kontak fisik dengan orang yang terinfeksi, menyentuh benda/permukaan yang telah terkontaminasi virus kemudian menyentuh wajah, mulut, hidung atau mata tanpa mencuci tangan. Oleh karena itu WHO merekomendasikan pencegahan infeksi virus ini dengan melakukan tindakan proteksi dasar seperti rutin cuci tangan dengan air pakai sabun atau alcohol, menjaga jarak dengan individu yang memiliki gejala gangguan pernapasan seperti batuk, pilek, bersin, menghindari kerumunan orang, dan melakukan etika batuk/bersin dengan baik (Susilo dkk, 2020; Kemenkes RI, 2020a).

Sejak semakin banyaknya orang yang terinfeksi COVID-19 tanpa menunjukkan adanya gejala, maka pemerintah menginstruksikan tambahan pencegahan dengan menggunakan masker saat keluar rumah (Satuan Tugas Penanganan COVID19, 2020).Selain itu beberapa pemerintah daerah juga telah memberlakukan penerapan Pembatasan Social Berskala Besar (PSBB) termasuk Kota Pekanbaru dengan tujuan untuk membatasi kegiatan tertentu serta pergerakan orang/barang dalam upaya menghambat peningkatan penyebaran COVID-19.Meskipun demikian beberapa kegiatan seperti pasar resmi yang melayani kebutuhan pokok masyarakat masih diizinkan beroperasi dengan catatan menerapkan physical distancing, hand hygiene, dan penggunaan masker (Keputusan Walikota Pekanbaru, 2020).

Berdasarkan hasil observasi di Pasar Dupa Pekanbaru, aktivitas social masih berjalan dengan normal meskipun dalam masa PSBB.Terlihat masih banyak para pedagang yang tidak memakai masker dan pengunjung pasar juga masih ada yang tidak pakai masker.Hal ini dapat menyebabkan tidak efektifnya penerapan PSBB dalam mencegah mata rantai penularan COVID-19, sehingga dirasa perlu untuk dilakukan kegiatan pembagian masker secara gratis pada para pedagang sebagai salah satu upaya untuk menghentikan penyebaran virus corona dari orang tanpa gejala.

Adapun tujuan kegiatan ini adalah untuk memutus rantai penyebaran COVID19 di Kota Pekanbaru serta meningkatkan kesadaran masyarakat untuk selalu menggunakan masker saat keluar rumah dan menjadikannya sebagai bagian dari perilaku hidup bersih dan sehat. Kegiatan ini juga bermanfaat untuk meningkatkan peran aktif masyarakat dalam mencegah dan memutus rantai.

\section{TARGET DAN LUARAN}

Sasaran kegiatan ini adalah para pedagang yang berjualan di Pasar Dupa Pekanbaru dengan target kegiatan adalah dibagikannya masker kain secara gratis pada para pedagang dan terjadinya perubahan perilaku para pedagang dengan selalu memakai masker saat berjualan di pasar. Sedangkan luaran yang diharapkan adalah terpublikasinya kegiatan ini pada jurnal ilmiah pengabdian masyarakat.

\section{METODE PELAKSANAAN}

Kegiatan pengabdian ini dilaksanakan di Pasar Dupa Pekanbaru pada tanggal 28 Juni 2020 dengan bentuk kegiatan berupa bakti social yaitu dengan membagi-bagikan masker kain secara gratis pada para pedagang yang ada di Pasar Dupa 
Pekanbaru. Sambil membagikan masker juga dilakukan pemberian informasi dan diskusi singkat terkait cara memakai dan merawat masker kain dengan benar.

Monitoring dan evaluasi dilakukan seminggu setelah kegiatan bakti social dilakukan yaitu pada tanggal 5 Juli 2020.Hal yang menjadi poin evaluasi adalah dipakainya masker oleh pedagang selama berjualan di Pasar Dupa.

\section{HASIL DAN PEMBAHASAN}

Pasar Dupa Pekanbaru merupakan salah satu pasar tradisional yang beroperasi setiap pagi hari sampai menjelang siang (sekitar pukul 11.00 - 12.00 WIB) setiap harinya. Pasar ini menjual berbagai kebutuhan sehari-hari masyarakat dengan letak yang strategis yaitu terletak di pusat kota dan di pinggir jalan utama Kota Pekanbaru sehingga setiap harinya pasar ini ramai dikunjungi oleh masyarakat.

Sebelum kegiatan pengabdian dilakukan, survey awal dilakukan untuk melihat kebiasaan memakai masker para pedagang.Setelah kegiatan pengabdian dilakukan dilihat kembali apakah telah terjadi perubahan perilaku untuk memakai masker saat berjualan.Hasil evaluasi didapatkan tidak terjadi perubahan yang berarti terhadap perilaku para pedagang untuk selalu memakai masker saat berjualan, masih banyak pedagang yang tidak memakai masker atau memakai masker dengan tidak benar saat berjualan.Saat ditanya kepada para pedagang, mereka mengatakan memakai masker terlalu lama membuat napasnya justru sesak, selain itu kalau memakai masker menyebabkan suaranya jadi kurang jelas terdengar oleh pembeli saat berjualan.

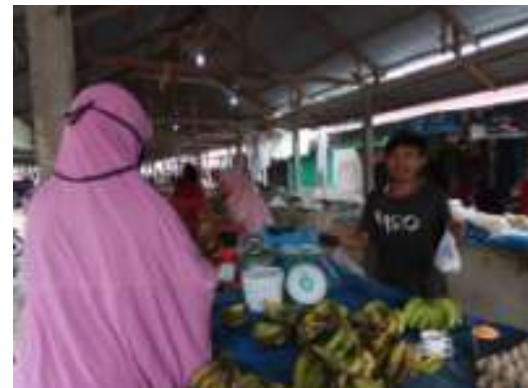

Gambar 1. Kegiatan Pembagian Masker

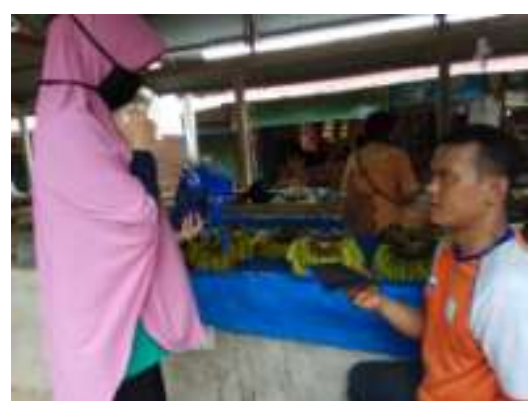

Gambar 2. Penjelasan Tentang Penggunaan Masker

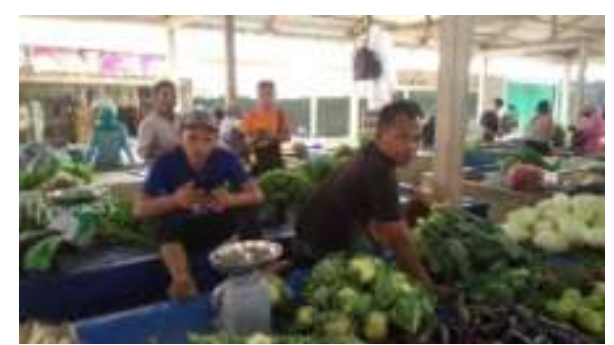

Gambar 3. Evaluasi kegiatan

Masker yang dibagikan pada kegiatan pengabdian ini adalah masker kain yang sesuai dengan standard kementrian kesehatan terdiri dari 3 lapis sehingga mampu menghasilkan proteksi sebesar 5070\% (Kemenkes RI, 2020b).Adapaun 3 lapis bahan masker kain ini adalah bahan taslan, spunbond dan katun.

Lapisan paling luar menggunakan bahan taslan. Bahan ini sering digunakan untuk material outdoor karena bersifat anti air, anti minyak, anti jamur, kuat, ringan, cepat kering, mudah dibersihkan sehingga cocok sebagai bagian luar dari masker yang mampu menahan percikan, debu ataupun droplet yang ada di udara sehingga tidak 
terhirup ke saluran pernapasan (Muthmainnah, 2018).

Sementara itu lapisan tengah masker menggunakan bahan spunbond. Bahan ini merupakan bahan kain nonwoven yang sering dipakai dalam dunia kesehatan karena merupakan bahan yang higienis seperti untuk pembuatan masker, tutup kepala dan pampers disposible. Bahan ini memiliki kelebihan bersifat kaku dengan serat kain yang rapat, tebal namun teksturnya halus sehingga mudah dibersihkan dan juga bersifat ramah lingkungan (Bahan kain, 2019).

Untuk bagian lapisan terdalam masker, digunakan bahan katun.Bahan katun merupakan bahan yang terbuat dari serat alami yaitu kapas sehingga memiliki tektur yang halus, lembut serta tidak membuat alergi.Selain itu bahan ini juga nyaman dipakai, kuat, tahan lama serta menyerap keringat, sehingga cocok sebagai lapisan terdalam masker yang langsung berkontak dengan kulit dan cenderung lembab karena uap udara dari mulut (Developer, 2020).

Sambil membagikan masker kepada para pedagang, tim juga menjelaskan terkait penggunaan masker kain, lama waktu penggunaan, dan cara pencucian. Penggunaan masker yang tepat harus menutup hidung, mulut dan dagu, maksimal dipakai selama 4 jam atau segera diganti saat masker telah lembab. Masker kain dapat dipakai kembali setelah dicuci dengan sabun/deterjen, jika perlu menggunakan air panas. Cuci tangan sebelum memakai masker dan saat akan melepas masker.melepaskan masker dengan memegang bagian tali masker, bukan bagian masker yang menutup mulut Masker yang telah dipakai disimpan sementara dalam kantong plastic tertutup untuk kemudian dicuci (Kemenkes RI, 2020b).

\section{KESIMPULAN DAN SARAN \\ 1. Kesimpulan}

Pencegahan penularan COVID-19 harus melibatkan peran serta secara aktif dari masyarakat, salah satunya pedagang. Salah satu cara pencegahan penularan COVID-19 adalah dengan memakai masker kain untuk individu yang merasa sehat/tidak. Namun hasil dari kegiatan pengabdian masyarakat ini menunjukkan masih rendahnya kesadaran masyarakat untuk memakai masker terlihat dari masih banyaknya para pedagang yang tidak memakai masker saat berjualan di Pasar Dupa Pekanbaru.

\section{Saran}

Disarankan untuk kegiatan pengabdian selanjutnya, bakti social berupa pembagian masker ini dapat dilanjutkan kembali dengan jumlah masker yang dibagikan lebih banyak mengingat kegiatan saat ini belum meliputi semua pedagang yang ada di Pasar Dupa dan belum efektif terhadap perubahan perilaku para pedagang untuk selalu memakai masker saat berjualan di Pasar. Selain itu untuk lebih meningkatkan kesadaran masyarakat dalam memakai masker, dapat diikuti dengan penempelan poster interaktif sebagai pengingat oleh masyarakat.

\section{UCAPAN TERIMA KASIH}

Terima kasih disampaikan pada Sekolah Tinggi Ilmu Kesehatan Hang Tuah Pekanbaru yang telah memberikan dukungan dana sehingga kegiatan ini dapat terlaksana dengan baik.

\section{DAFTAR PUSTAKA}

Bahan kain.(2019). Mengenal bahan kain spunbond. Diakses dari https://www.bahankain.com/2019/03/ 29/mengenal-bahan-kain-spunbond

Developer.(2020). Karakteristik kelebihan dan kekurangan bahan katun. Diakses dari https://tokoharits.com/blog/karakterist 
ik-kelebihan-dan-kekurangan-kainkatun/

Kemenkes RI. (2020a). Apa yang harus dilakukan masyarakat untuk cegah penularan COVID-19?. Jakarta: Kemenkes RI.

Kemenkes RI. (2020b). Flayer bagaimana memakai masker kain yang aman. Diakses dari www.promkes.kemkes.go.id

Keputusan Walikota Pekanbaru. (2020). Pemberlakuan PSBB dalam penanganan COVID-19 di Kota Pekanbaru. Diakses dari https://covid19.hukumonline.com/wpcontent/uploads/2020/04/keputusan walikota_pekanbaru_nomor_325 tah un_2020-1.pdf

Muthmainnah. (2018). Kain taslan: Kelebihan, kekurangan, karakteristik, jenis. Diakses dari https://olympics30.com/kain-taslan/

Satuan Tugas Penanganan COVID19.(2020). Data dan peta sebaran.Diakses dari www.covid19.go.id

Susilo, A., Ruende, M., Pitoyo, W.C., Santoso, W.D., Tulianti, M., Herikurniawan., ... Yunihastuti, E. (2020). Coronavirus Disease 2019: Tinjauan Literatur Terkini Coronavirus Disease 2019: Review of Current Literatures. Jurnal Penyakit Dalam Indonesia, 7(1), hal 45-67. 